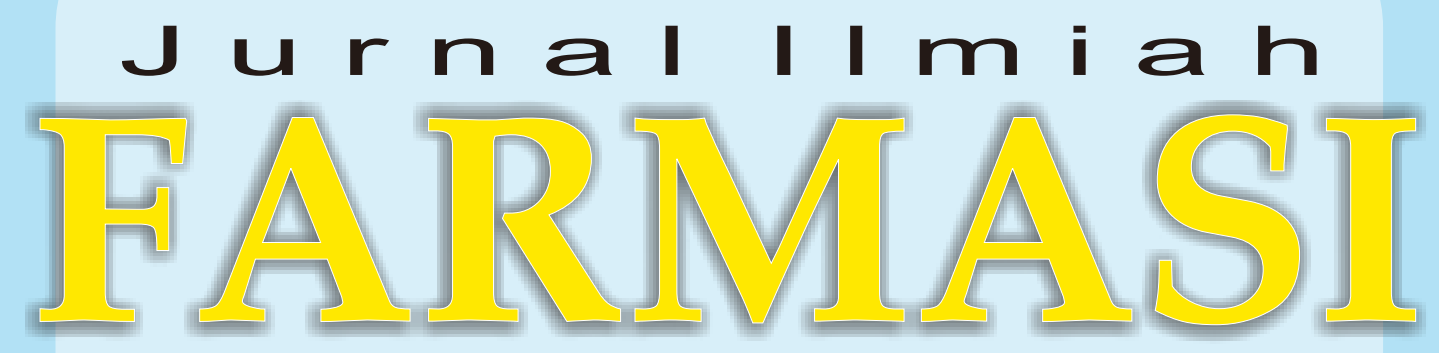

(Scientific Journal of Pharmacy) 
JURNAL ILMIAH FARMASI

(SCIENTIFIC JOURNAL OF PHARMACY)

PIMPINAN UMUM/ PENANGGUNG JAWAB

Dekan Fakultas Matematika dan Ilmu Pengetahuan Alam

Universitas Islam Indonesia

WAKIL PIMPINAN UMUM/ WAKIL PENANGGUNG JAWAB

Ketua Jurusan Farmasi FMIPA UII

\section{MITRA BESTARI}

1. Prof. Dr. Wiryatun Lestariana, Apt

2. Prof. Dr. Zullies Ikawati, Apt

3. Prof. Dr. Sudibyo Martono, Apt

4. Dr. Tedjo Yuwono, Apt

5. Prof. Dr. Dachriyanus, Apt

6. Prof. dr. Iwan Dwiprahasto, MMedSc, PhD

7. Prof. Dr. Lukman Hakim M.Sc., Apt

8. Prof. Dr. Achmad Fudholi, DEA, Apt

9. Prof. Dr. Ibnu Gholib Gandjar, DEA., Apt

\begin{tabular}{ll} 
& \multicolumn{1}{c}{ DEWAN EDITOR } \\
Ketua & : Saepudin, M.Si., Apt \\
Sekretaris & : Rochmy Istikharah, M.Sc., Apt. \\
Anggota & : Vitarani Dwi Ananda Ningrum, M.Si., Apt \\
& Okti R. Mafruhah, MSc., Apt \\
& Dimas Adhi Pradana, MSc., Apt. \\
& Fithria DA. Suryanegara, MSc., Apt. \\
& Ari Wibowo, S.Farm., Apt \\
& Arba Pramudita Ramadani, MSc., Apt. \\
& Oktavia Indrati, S.Farm., Apt.
\end{tabular}

Penerbit

Jurusan Farmasi Fakultas Matematika dan IImu Pengetahuan Alam Universitas Islam Indonesia

Alamat Penerbit Jurusan Farmasi FMIPA UII

Jl. Kaliurang Km. 14,4 Yogyakarta 55584

Telp. (0274) 896439 ext. 3047

Email: jif@uii.ac.id 


\title{
ASPEK FARMAKOLOGI TETRAHIDROKURKUMIN: METABOLIT UTAMA KURKUMIN
}

\author{
Agung Endro Nugroho
}

Fakultas Farmasi, Universitas Gadjah Mada

\begin{abstract}
Tetrahydrocurcumin is a main metabolite product from biotransformation process of curcumin in the body. Biotransformation of curcumin is fast and occurred during absorption process in gastrointestinal tract. The biotransformation of curcumin to tetrahydrocurcumin and the stability of tetrahydrocurcumin play important roles in the biological effects of curcumin in the body. The present article discussed about the pharmacological aspects of tetrahydrocurcumin. Tetrahydrocurcumin was reported possessing several pharmacological activities such as: antioxidant, anti-inflammatory, hepatoprotector, anti-allergy, protective for atherosclerosis and renal damage, and also anticarcinogenesis. It's main pharmacological activity is antioxidant, which is underlying and responsible for the other activities. The antioxidant activity of tetrahydrocurcumin was reported better than this of curcumin. The main factors for the antioxidant or free radical scavenger effects of tetrahydrocurcumin are it's aromatic/phenolic hydroxy and $\beta$-diketon moieties.
\end{abstract}

Key words : tetrahydrokurcumin, curcumin, pharmacology, antioxidant 